\title{
Before The Sheik: Rudolph Valentino and Sexual Melancholia.
}

\begin{abstract}
:
Once he was cast as the powerful, yet sexually-on-display Ahmed Ben Hassan in The Sheik (George Melford, 1921), Rudolph Valentino rose to super-stardom, the bearer of a conflicted image defined by a fragmented patriarchal discourse. The enduring resonance of the 'Sheik' identification, combined with a lack of critical attention to Valentino's performance, have obscured the different qualities he projected in earlier leading roles, at the dawn of his star trajectory. This paper focuses on Valentino's three other surviving films from 1921, which preceded The Sheik in rapid succession. It argues that here Valentino's narrative roles, and most especially his performance, are increasingly defined by a sense of loss, powerlessness, and lack of control, informing his predominantly erotic function on screen. Drawing on the work of Leo Bersani and Sigmund Freud, this paper highlights how a key strand of Valentino's performance suggests the body's failure to control and connect with the world beyond the Self. In an expression of sexual melancholia, Valentino's intensity of desire, mourning, and pain marks his physical presence, constructing an erotic identity that attempts yet always fails to defer loss. In contrast with his 'sexual menace' image, cristallised by the Sheik persona and tempered by his ambivalent relation to the gaze, in these earlier films Valentino provides a different antidote to patriarchal brutality, embodying the essentially melancholic nature of erotic experience.
\end{abstract}


The opening of Camille (Ray C. Smallwood, 1921) introduces its male protagonist Armand Duval (Rudolph Valentino, fig.1) through his first, fateful encounter with Marguerite Gautier (Alla Nazimova, fig.2), the woman he will be obsessed with throughout the film. This crucial scene is set in the busy foyer of an elegant Paris theatre, which Armand is about to leave in the company of his friend Gaston Rieux (Rex Cherryman). As the two young men chat and make their way down the central staircase, Gaston points out Marguerite at some distance from them: she dazzles in a heavily ornate gown, her naked shoulders visible under see-through fabric, and her luxuriant dark hair framing her face in loose curls. A throng of admirers vie for her attention. Up to this moment, Armand has appeared at ease, in tune with his leisurely surroundings; once he sees Marguerite, however, his relaxed posture is broken. Frozen in amazement for a second, he dilates his eyes, then takes a single step towards her and stops again, his whole body rigid with alertness (fig.3). Valentino's movements are brief and seen in a long shot, but they manage to convey total enrapture. Gaston next waves at Marguerite, as Armand keeps perfectly still, with his gaze glued on her; when she reaches the staircase mezzanine, on a level with the two friends, Gaston grabs the chance for a formal meeting. 'Permit me to introduce a fellow law student' says the intertitle. Armand bows to Marguerite, who intently looks him over and then turns slightly towards her companions, while still facing him sideways. Her sensuously made-up face is shot in close-up, and her mouth is halfcovered by her hand as she affects a whisper, clearly and seductively aimed at Armand (fig.4). Her words appear on screen: 'A law student? He'd do better to study love!'. Armand's reaction to this playful erotic flirting is extraordinary. As the camera closes in on him, he grimaces in pain, his eyes moving away from Marguerite to rest, deeply sad, on a vacant point in front of him; his mouth is cast downwards (fig.5). 
Valentino holds this expression of distress, thus subtly reinforcing it, suggesting the possibility of impending tears. Wholly in excess of narrative motivation, his performance points to a mysterious inner drama just starting to unfold. Marguerite's group now moves further down the stairs, laughing and talking amid the crowd, leaving Armand motionless and isolated at the left of the frame; Gaston, though not far from him, is turned the other way talking to Marguerite's sister, Prudence (Zeffie Tilbury). A medium-long shot captures their figures: Gaston and the lady chatting light-heartedly, Armand static and vacant as a statue, seemingly absorbed in a painful reverie (fig.6). As the camera cuts between Marguerite and her admirers in lively conversation, Gaston and Prudence sharing a joke, and Armand on his own, the latter's mute, immobile appearance is strikingly out of key; not even his hands, holding his hat, have as much as twitched, and his lips have not moved once. However, movement and action return to Armand as he learns he may see Marguerite again. As Prudence suggests they go immediately to her sister's place, to attend an impromptu party, Armand is shaken out of his trance: suddenly turning towards Gaston, who seems uncertain about the proposal, he eagerly squeezes his friend's arm, indicating his urgency to follow Marguerite. His face retains a grave look of sadness, but his eyes are alive with pleading (fig.7). Again, Valentino's shifting countenance is on screen only for a few moments, yet the intensity of his performance suggests unbound desire and pain.

In this brief scene, by expressing specifically strong feelings in rapid succession, Valentino initiates a performative pattern that begins with live shock, turns into anguished disconnection, and is followed by return to a troubled focus on the present; what triggers and sustains the pattern is Armand's powerful attraction for Marguerite. Valentino's performance comes full circle later on in Camille, when his isolated 
stillness gives way to an open admission of frenzied need. As the film cuts to a long sequence set in Marguerite's home, which has been taken over by her rowdy party, Armand looks constantly separated from what is going on; mostly confined to the edge of the frame, either standing up or uneasily sitting down, he does not join the merry antics of the group, indeed he does not even speak. Marguerite occasionally directs a flirtatious gesture or word to him, but her attention is all the time diverted by her other guests; on a couple of occasions, she entertains them by singing some raucous songs. These scenes are intercut with close-ups of Armand, whose unhappy eyes are either fixed on Marguerite or staring blankly. Prior to Armand's arrival, Marguerite had been shown fleeing briefly to her bedroom. In the privacy of this chamber she had nearly collapsed, looking exhausted and close to faint; when her maid had solicitously arrived, remarking that she was ill, Marguerite had affectionately dismissed her, soon resuming her role of lively hostess. Well after Armand's arrival, with the party in full swing, Marguerite starts to cough violently and slides again into her room, among general unconcern. Only Armand shows alarm, and follows her alone to the bedroom. A dialogue between them has hardly started when Marguerite, showing irritation at his attentions, tells him to leave. Armand instead falls dramatically on his knees, clasps her legs in his arms and presses his face against her body (fig.8). Nazimova's aura of confident self-possession does not fail her (and indeed it had remained visible even in her fainting fit), and she calmly strokes Armand's hair, even after his remarkable utterance: 'I wish I were a relative your servant - a dog - that I might care for you - nurse you - make you well!'. Marguerite tries in vain to defuse his fervour: he clings to her legs, now looking up at her in despair, and as she finally frees herself from his grasp, he gets up and once 
again encircles her in his arms. His frantic, supplicating attitude expresses not only overwhelming need, but an equally colossal fear of losing her.

This is all a far cry from the 'sexual menace' persona that significantly defines Valentino in other films. In particular, Armand's behaviour could not be more remote from that of Ahmed 'the Sheik', ${ }^{1}$ whose patriarchal brutality may indeed be parodic or fragmented, ${ }^{2}$ but which nonetheless associates mastery and aggression with Valentino's most enduring screen image (fig.9). At the same time, Valentino's look of profound sadness in these scenes of Camille, his paralysing isolation and chaotic neediness, are equally out of register with the film's overt narrative, which presents a series of fairly mundane events. Armand's distressed behaviour starts with his first sight of Marguerite, of whom he knows nothing; while clearly if inexplicably sparked by attraction, his pain and shock cannot be linked to Marguerite's illness, still unknown to him, and which remains undefined even through later developments. When Armand throws himself at Marguerite's feet, in the culmination of his expressive cycle of anguished desire, he has merely seen her cough once. Only after Armand's prostration does Marguerite say 'my life is not for long', and that rather casually and without elaboration. Valentino's performance, therefore, is not reducible to his character's circumstances, ostensibly just those of a man hit by passion at first sight. Alongside Camille's dominant narrative, Valentino's acting suggests another story, that of Armand's hidden yet implied drama; while still resting on the film's ready-made elements, from plot twists to dialogue intertitles, this drama exists in its fullness on a wholly different level of meaning. As Andrew Klevan has argued, a close reading of actors' performances 'can reveal other stories that are less immediately apparent ${ }^{3}$, while not blotting out the performer's acknowledgement of 
the film's leading signifying layer. The actor who 'resists asserting a single emotional response ${ }^{4}$ to his or her character's situation, effectively allows other interpretative possibilities to emerge. In Camille, Armand's alternative story is coded through Valentino's precise, yet multilayered performative pattern, a structure of personal distress that outdoes, without denying it, factual narrative progression. It is not, however, a pattern unique to Camille.

This paper wishes to argue three points; first, that Valentino's peculiar display of sadness, isolation and frenzy is also present in The Four Horsemen of the Apocalypse and, to a briefer extent, in The Conquering Power (both from 1921, directed by Rex Ingram), the two surviving films from his early stardom which, together with Camille, preceded The Sheik in rapid succession. Secondly, that this particular thread in Valentino's performance is not simply relevant to cinematic language, but that it may be read as the dramatisation, or evocation, of a physical and erotic experience which will be termed 'sexual melancholia'. Lastly, that sexual melancholia provides a counter discourse to orthodox masculinity, and is thus an important manifestation of Valentino's unsettling relation to patriarchy.

A number of scholars have deconstructed Rudolph Valentino's star image, exposing the deeply ambiguous aspects of his gender identity. As an intensely eroticised, exoticised object of desire, Valentino cannot be contained by his often hyper-virile impersonations, occupying instead a fluctuating, precarious location in the economy of the gaze. Appearing in turn as prey and predator, passive and active, perfect gentleman and kidnapping brute, he transgresses on screen the masculine boundaries he himself sets. With an off-screen persona defined by staggering ambivalence, from the ideal masculinity of the Great Lover to the perceived effeminacy of the exquisitely groomed 'Powder Puff', from stud-like athletic appearances to the wearing of a 
'slave' bracelet given to him by his wife, Valentino disrupts patriarchal power without and within the diegesis. Even in his most stereotypically masculine roles, therefore, Valentino has been found to be subverting gender dynamics, and scholars have paid special attention to his duality. The streak of sadism he exhibits in some of his films, for instance, is offset by an equally notable vein of masochism; Miriam Hansen notes how, in The Son of the Sheik, Valentino's behaviour towards his love interest Yasmin (Vilma Banky) includes revenge through 'a veritable one-eyed stare with which he transfixes her to the point of rape', yet Yasmin is partly vindicated by 'the powerful image of him crucified, humiliated, and whipped earlier on in the film'. ${ }^{5}$ Also discussing this 'rape' scene, Gaylyn Studlar adds that here Valentino's highly stylised, dance-like movements discourage interpretations of sexual assault, while instead 'controlling and containing the vicious and brutal aspects of male behaviour' through a 'feminized mode of expression'. ${ }^{6}$ A different strand of Valentino-related scholarship, also stressing his non- or anti-patriarchal side, includes the work of Thomas J. Slater, who assesses the scripts of key Valentino films. These are scripts written by Valentino's mentor June Mathis, one of the most powerful women in 1920s Hollywood, responsible for The Four Horsemen, The Conquering Power, and Camille, among others. According to Slater, the characters Mathis builds for Valentino are 'damaged' males, who ultimately endorse non-violent, positive alternatives to traditional virility. ${ }^{7}$ In his archival-based research on Valentino's stardom and reception, Mark Glancy also stresses the ambiguity of his masculine image: discussing Valentino in The Sheik, he points out that 'any sense of brutality or danger is undermined by his strikingly androgynous outfit', and that his screen presence as a leading man, throughout his career, betrays 'a complicated sexuality that could swing from dominance to submission'. 
While film scholars have provided precious insights into Valentino's image, and into the historical and cultural context of his stardom, his screen presence has not been explored in full; most notably, Valentino's performance has been largely ignored. This paper wishes to expand the discussion of his deviant masculinity, as well as offer an appreciation of his acting skills; by focusing on specific features of Valentino's performance, it aims to explore his unorthodox articulation of desire, which challenges tenets of virility and of erotic experience at the same time.

The Four Horsemen of the Apocalypse is an epic, rambling tour-de-force that moves from the dance halls of Buenos Aires to the French trenches of WWI. Rudolph Valentino plays Julio Desnoyers, a young Argentine of French ancestry, who enters the film as a caddish tango champion and ends up as a war hero. Most of Julio's part, however, is set in Paris, where his family moves back early in the film, and where the plot centres on his passionate romance with Marguerite Laurier (Alice Terry), a woman tied to a husband she does not care for. Although she is offered a divorce when her affair with Julio is discovered, Marguerite eventually rejects the call of love in favour of duty: she enlists as a nurse as WWI breaks out, leaving Julio distraught and, unlike most men around him, still a civilian, as his Argentine birth protects him from the French draft. Only towards the end of the film does Julio enlist in the French army, finding meaning and purpose in sharing the painful struggle around him; he is sent to the front, where he is killed by an artillery shell.

A redemptive tale of masculine valour, with strong pacifist and humanist implications, The Four Horsemen is also very much a platform for Valentino's sexappeal; the tango sequence which introduces him, a breath-taking display of heavily eroticised dancing, unequivocally establishes him as the film's sex symbol. While his 
character undergoes vast changes in behaviour and outlook, pacing the 'transforming' path that Slater ascribes to Mathis's script, Valentino's main function remains the same: he is both the focus and locus of eroticism. Alice Terry is exquisitely pretty, but not remotely sexualised by the film, and by being Valentino's partner she merely draws attention to his desire. Though ostensibly caught in a smouldering passion, Terry is always demure and composed, almost prim. In Camille, on the other hand, Nazimova could never be described as prim, yet she equally lacks the erotic charge that defines Valentino, not least because of her convincing impersonation of a terminally ill consumptive. In both films, as well as in The Conquering Power which stars again Alice Terry, Valentino is the screen's sex magnet. However, while his eroticised function stays constant, it is variously shaped and taken over by his performance, suggestive of meanings beyond the main plot; at the same time, these new meanings remain tied to the realm of the erotic, the framework that gives Valentino his primary signifying value. In the beginning of The Four Horsemen, and of The Conquering Power to a milder degree, Valentino's presence is sexually confident to the point of aggression, achieving a match between acting and narrative role: as a tango rogue in the first film, a rich womaniser in the second, he seemingly dominates his women and surroundings alike. This uncomplicatedly brash style, however, increasingly gives way to a different mood, indicative of sadness, loss, and lack of control, which becomes Valentino's prevailing mode of expression. The result is an erotic identity strongly informed by his distressed performance, pointing to an experience of desire that must account for dejection and isolation, as well as powerlessness: altogether, a problematic impersonation of the sexuality, and even the personality, of a 'great lover'. 
In a key scene of The Four Horsemen, at a stage in the film when Julio and Marguerite are still forced to hide their love story, Julio's situation comes to a crisis. The moment finds them together at his place, initially enjoying their romantic rendezvous; although the beginning of WWI is looming around them, they are oblivious to it, wholly engrossed in each other. She is sitting on a sofa and he very close to her, on a stool in a slightly lower position; as the camera frames them in medium close-up, Julio takes one of her hands and holds it in both of his, caressing it and kissing it, in a faintly nervous display of possession. A lot has been written on Valentino's idiosyncratic hand-kissing, a peculiarly deliberate, sexualised gesture that he repeats in all his films; as Mark Glancy observes, a marked pause usually precedes the moment of kissing, emphasising the fetishist value placed on the woman's hand. ${ }^{9}$ What also needs to be noted, however, is how Valentino's manner shows a certain anxiety, a restless touching which, being usually the only physical contact present at this moment, suggests a compulsive need for connection and the almost impossibility of letting go. In Freudian terms, as will be discussed shortly, Valentino's treatment of his lover's hand expresses his 'clinging to the libidinal object'; this clinging is all the more apt because separation is, or may be, drawing closer. In The Four Horsemen, this particular hand-kissing is immediately followed by Marguerite's confession, the fact that she is still acquiescing to her husband's sexual demands; the implied meaning of her revelation is that Julio's rights to her body, far from being secure or exclusive, are precarious and partial. At this point, narrative conventions may expect Julio's reaction to be one of jealousy, perhaps rage; through his performance, however, Valentino provides a different spectacle. As soon as she tells him of her husband's sexual prerogative, merely hinted on screen through a brief flashback, Julio turns his face away from Marguerite; in a second, he assumes a stunned, deeply sad 
expression, his eyes first staring in front of him and then looking down, in acute distress (fig.10). Marguerite continues to talk, but he seems unreachable by her words, having entered a painful dimension of his own; he is keeping perfectly still. The close framing does not give a view of their hands, but Valentino's frozen posture and remote gaze suggest full detachment. This suffered disconnection, and the contemplation of something terribly sad, thus define his reaction so far; the whole performance has lasted thirty seconds, but its intensity is remarkable. He then slowly turns his face in Marguerite's direction, yet only to look away again, simultaneously holding her in a curious embrace: his arm is around her and he pats her shoulder almost mechanically, while looking fixedly ahead with eyes wide-open. His expression is both unhappy and fearful (fig.11). Then suddenly, in a marked change of pace, he looks and speaks directly at her, so frantically as to cause her to stand up, almost recoiling from him. Valentino does not let go of her body, as he also gets up, holding her very tight and placing his hand on one of her breasts (fig.12). His words appear on screen: 'You do not belong to him - you belong to me!'. This may read as a conventionally jealous statement, but through Valentino's vulnerable, disoriented performance it becomes a pure cry of anguish. Marguerite shakes her head and speaks, seemingly trying to calm him down, but his frenzy only increases. He wildly caresses her body and kisses her neck, almost plunging his face into her flesh, all the while keeping his hand on her breast: this latter gesture, prominently displayed at the forefront of the frame, increases the erotic dimension of the scene, which is remarkable even for pre-code Hollywood. Sex, however, is not the only suggestion of Valentino's behaviour, as his look and movements appear panic-stricken: this is erotic frenzy in the face of unbearable dread. While Valentino's performance punctuates a brief yet significant plot development, namely the discovery that Marguerite is still 
subject to her husband's sexual power, it also exceeds narrative content: after all, Marguerite is not dying, nor does she love someone else. The alternation of shock, melancholy and disconnection that externalise Julio's response, and the manic physicality that follows it, mirror Armand's response to meeting Marguerite in Camille; yet unlike Julio, Armand has no previous association with the woman he craves. The link between these scenes is the protagonists' erotic passion, rather than their narrative circumstances. Armand's behaviour, triggered by his instant fascination with Marguerite, highlights his prior and catastrophic knowledge not of a specific object of desire, but of the experience of desire in itself. In both films, the presence of the hero's personal, secret drama is emphasised by the contrast between his reactions and those of the woman next to him. Nazimova looks flirtatious and flattered in Camille, yet her immediate attraction for Armand, which she openly acknowledges, brings not a hint of behaviour comparable to his. In The Four Horsemen, Terry plays the character that is directly affected, even harassed and violated, by her husband's sexual contact; but it is Valentino who shows enormous distress, not her. Indeed, Terry's composure only increases as the film goes on, marking its difference from the performance of Valentino who, as Julio, looks instead more and more upset. The performative gap between them gives also extra poignancy to his isolation, to the frozen self-detachment he injects into key scenes. At another critical moment, when Marguerite is preparing to join the war nurses and thus the war effort, Valentino repeats his disconnection-connection pattern with almost balletic precision. The scene shows Marguerite adjusting her Red Cross veil in front of a mirror, turning around to check her outfit with rapid, confident movements; the hint of a smile plays on her lips. Julio sits in a corner at the back of the frame, watching her with a deeply sad expression. He is quite still, his shoulders drooping in a slight 
hunch as in defeat, his hands held together in his lap; he appears self-contained, cut off from what is going on. Yet as Marguerite goes to him at last, he stands up and smiles invitingly, moving closer to her for a kiss: he stops dead, however, when his eyes catch sight of the large cross on her nurse headpiece. In a flash, Julio looks distressed to the point of horror (fig.13), and he averts his gaze while turning away from her. Marguerite seems annoyed and uncertain as to what to do, then she starts to remove her veil; meantime Julio keeps his separate posture, now virtually petrified in complete stillness. Even his hand, which he had raised to hold the edge of her veil, is suspended in that position as if struck by a spell. With his infinitely sad eyes, his brow knotted as in disbelief, and his mouth turned downwards, Valentino's face is a mask of grief (fig.14). He does not seem to heed Marguerite, who is now again bare-headed and talking to him; then finally, slowly, he turns towards her, and suddenly grabs her in a passionate kiss.

At the film's dominant level of meaning, Julio has been expressing the painful shame caused by his non-participation in WWI; with even his woman joining the cause, his failure to show masculine bravery is all the more poignant. At the same time, this scene is emphatically, if unnecessarily framed by an erotic dimension, as Julio's awkward position in relation to France's war has no link to a kiss between lovers. Similarly, Valentino's extreme physical self-isolation, and his extraordinary look of sadness, cannot be fully explained through narrative events. Just like Armand's peculiar distress seems wildly disproportionate in Camille, so Julio's behaviour in these two scenes vastly exceeds plot motivations. Constructed and linked by Valentino's performance, an alternative story lies behind Julio and Armand. In order to reveal this story, it is useful to begin by considering Leo Bersani's observations on erotic experience. 
Bersani starts what is probably his most famous essay, Is the Rectum a Grave?, with a typically provocative statement: 'There is a big secret about sex: most people don't like it'. ${ }^{10}$ After qualifying this claim by saying that to like sex and to feel the need for it are 'wholly different' issues, Bersani goes on to insist that most people, regardless of their views and inclinations in regards to sexual desire, share 'a certain aversion' for it (Bersani's emphasis). Explaining that this aversion can take a 'malignant' form, such as the virulent homophobia unleashed by the 1980s AIDS epidemics, or a 'benign' form, Bersani considers the latter through an interesting yet deliberately narrow prism. Chiefly concerned with the power structures governing human relations, and with their link to sexual activity and feelings, he argues that anatomy plays a key part in a sexual framework resting on the interplay of 'mastery and subordination'. The aversion associated with the sexual sphere has its roots in the inevitable 'exercise or loss of power' that desire and its consequence entails. ${ }^{11}$ Exploring the nature and experience of this power, Bersani discusses the 'aversive' discourse attached to powerlessness, and proposes instead a hopeful assessment of any sex leading to a 'radical disintegration and humiliation of the self' ${ }^{12}$ Having thus nailed any disturbing connotations of the erotic realm to a (certainly important) revisionist look at power dynamics, Bersani is unable or unwilling to open up his own notion of 'aversion'. In passing, however, he does make a very interesting comment: he suggests that the power unbalance present in human relations, and markedly evident when these relations are sexual, 'may be grounded in the shifting experience that every human being has of his or her body's capacity, or failure, to control and manipulate the world beyond the self'. ${ }^{13}$ Because of his stated interest in power narratives that imply 'mastery and subordination', Bersani ignores how control and 
manipulation may serve other functions apart from physical supremacy or the imposition of will; nor does he consider how there may be other reasons causing aversion to, or a distressing experience of, erotic feelings. Yet implicitly, Bersani admits this latter possibility. For while he insists that sex, for the purpose of his argument, refers to specific physical acts and social interactions, he also vaguely allows, through 'the shifting experience that every human being has of his or her body...' the prospect that aversion to sex may be linked to something else too, something pertaining to bodily and erotic feelings in themselves: that is, to the bodymediated relation (or experience of that relation) between the self and the external world, a shifting relation, which therefore must eventually return to failure as regards the body's control of what lies outside it. And within the infinite variety of the world outside the body, it is some other bodies, objects of desire and receptacles of loved personalities, that constitute the most obvious target for control. To control something or someone does not necessarily imply to subjugate it: it also entails the idea of connection, as 'control' rests by default on an assured connective structure. The aversion towards the sexual that, Bersani argues, is shared by most people, may also be caused by the body's inherent capacity to burden the self through its experience of an essential disconnection. Intermittently yet inevitably, the body fails to feel connected with the desired outside world, or loses its connection with it: to be embodied means, among many things, to experience shifting isolation and loss. The erotic sphere is a poignant location for this bodily-induced disconnection, and for the state of distress and separation that may result from it. Indeed, Bersani himself hints at the likelihood that sexual feelings, or the process of acting upon those feelings, may be innately upsetting: in another essay entitled Can Sex Make Us Happy?, he discusses at length Sigmund Freud's complex views on the link between the sexual 
and aggressive drives. ${ }^{14}$ While Bersani's prime interest lies in the problematic conflation of sex with aggression, he casually mentions Freud's equally casual remark in Civilization and Its Discontents, the observation that 'something inherent in the [sexual] function itself denies total satisfaction...'. ${ }^{15}$ Whatever this 'something' may be, neither Freud nor Bersani choose to discuss, but the latter describes Freud's suggestion as a 'disturbing possibility'.

Going back to Rudolph Valentino, it seems evident that his performance, in the specific instances and patterns described, links the erotic sphere to something quite disturbing indeed. With a presence marked by sexualised physicality, an idiosyncratic use of his body, and striking facial expressions, Valentino constructs an experience of the erotic lived through sadness and disconnection. To explore a possible way in which the specificity of this experience may be understood, it is valuable to turn to Freud himself. Freud devoted a lot of work to the study of inexplicable sadness, although he did so in a context that privileged the mind to the exclusion of the body. ${ }^{16}$ In his essay 'Mourning and Melancholia', he describes the melancholic state as a set of psychic and behavioural symptoms which replicate those encountered in mourning; however, the puzzling (and assumedly pathological) nature of melancholia lies in its lack of an obvious object to mourn. Yet just like the person who has experienced the death or loss of a loved one, the melancholic subject presents a spectacle defined, first of all, by a 'painful frame of mind', a 'loss of interest in the outside world', ${ }^{17}$ and the concentration of an enormous amount of psychic energy, or 'cathexis', on a tragedy which seems to have occurred. ${ }^{18}$ Like the mourner, the melancholic is overwhelmingly, painfully focused on something lost, and remains oblivious to everything else. In regards to Valentino, this description starts to make sense when his 
performance is considered in a double light, in reference to both his mysterious distress and the suggestions of Bersani's work. Valentino's displays of remote selfcontainment, his frozen absorption by something terribly sad, certainly appear to illustrate acute melancholia, or inexplicable mourning: as previously observed, the films' plots do not furnish any obvious loss or catastrophe to justify such grief. What the films do provide is a narrative when, in each case, Valentino's pain emerges through his relation to a woman he is irresistibly attracted to. There may have been a slight loosening of their exclusive connection, as in The Four Horsemen, when Marguerite reveals her husband's sexual prerogatives, or when she becomes wholly involved in her nursing duties; or, as in Camille, the mere sight of a woman's beauty and allure, devoid of any previous association, may be enough to spark this distress. Crucially, in all these scenes, Valentino's melancholic mood of distant selfconcentration excludes even the woman who has triggered it. This behaviour is instantly comprehensible if one posits that what is being mourned is not the woman herself, but what she represents: the shifting link to the outside world, and thus the inevitable separation from it. As if innately aware of the body's fate of suffered disconnection, Valentino's characters are thrown into melancholia by a loss evoked through erotic attachment. The desired body is always, already potentially lost to the subject, and this loss is brought into focus by the sheer power of erotic feelings, or by a sudden decrease of connection with the object of desire. While this melancholic stage is emphatically present at the beginning of Camille, and equally evident in the scenes from The Four Horsemen previously discussed, it is also noticeable in The Conquering Power. 
Adapted from Honoré de Balzac's novel 'Eugénie Grandet', The Conquering Power focuses on the lives of cousins Charles and Eugénie Grandet (Rudolph Valentino and Alice Terry), whose mutual passion is ridden with obstacles, mostly due to the scheming of Eugénie's miserly father, Père Grandet (Ralph Lewis). In a pivotal scene of the film, the bankrupted Charles has fallen asleep crying, as he is forced to emigrate to make his fortune, leaving behind Eugénie whom he has secretly fallen in love with; at this stage in the plot, he has no idea that Eugénie loves him too. He is staying at the Grandet house while waiting to sail for the colonies, and has succumbed to exhaustion while writing letters at night. Eugénie finds him asleep at his desk, and cannot resist glancing at the letter he has just composed: from this she learns that Charles loves her. Moved and excited by the revelation, she resolves to give him all her savings, the gold coins she has received from her father, to help him in his difficult enterprise abroad. As she softly steals upon Charles, still slumbering in his chair, he wakes up and sees her. Eugénie asks him to forgive her for having read his letter, then she kneels on the floor next to him; as Charles is still disoriented by the uncovering of his love for her, she places her gold fortune in front of him. Charles's immediate reaction is to refuse it, despite Eugénie's entreaties that 'to borrow from a cousin is like borrowing from a sister'. The notion that she sees herself as a surrogate sister rings clearly false, given the intense, love-struck way she looks at him; Charles grows agitated and distressed, then stands up and looks away from her. An air of heavy sadness spreads over his face. Eugénie timidly touches his arm, gazing upon him with beseeching eyes; her offer of everything she possesses, her manner, combined to her knowledge of his love for her, must signal to Charles that his passion is reciprocated. The implication of all this is that intimacy, emotional and erotic, is sure to happen between them. At this point Valentino is still standing, his body rigid 
and frozen, his arms dropped by his sides; as the camera gets closer to his face, it shows the customary appearance of a mask of grief (fig.15). It is a very brief shot, but the sadness of Valentino's expression is remarkably intense. Slowly, he turns towards Eugénie, and his features relax as he puts a condition for accepting her gold: she must agree to receive his most precious possessions, the only remaining gifts from his parents. He rapidly goes out of the room and returns with his treasures, a gold box and two miniature portraits; Eugénie's acceptance of these objects will seal their bond of intimacy. And indeed, after only a little resistance, she mutely accepts them. The exchange now complete, they can both exult in the unexpected arrival of love and hope. Charles takes her hand and draws her closer to him, while she looks at him with rapture: their posture suggests the prelude to a kiss. Yet at this precise moment Valentino turns his face away, looking in the distance with a frown, as if he had suddenly remembered something unpleasant; in a flash, his eyes assume a frightened, pained expression. His mouth quivers, and his whole face indicates torment (fig.16). Next, turning his eyes to Marguerite's hand he is still holding, he regards it for a few seconds, places his other hand around it too to better caress it, and covers it with kisses. Without a look at Marguerite, he then lets her hand go, turns his whole body away and resumes his lone position by the desk; their connection, for the moment at least, has clearly expired. Marguerite can only run out of the room.

As previously observed in regards to comparable moments in Camille and The Four Horsemen, Valentino's performative pattern is not concluded by separation, but progresses to a re-connection attempt, expressed through a clinging and frenzied attitude towards the desired object. In The Conquering Power this moment is delayed by various narrative factors. One is the other plot strand in the night-time sequence, the presence of Marguerite's father who, instead of sleeping, patrols the house with a 
rifle, obsessed by the thought of burglars stealing his money. Another is the fact that Charles and Marguerite, having missed this first chance for intimacy, are constrained by the family setting and their relation as cousins. Equally, Charles's belief that he is penniless (as the knowledge that he is in fact rich is being hidden from him by Père Grandet) prevents him from binding Marguerite to him; while Marguerite is just exceedingly shy. Even so, Charles's departure from France provides the occasion for revelation, and for the closing act of Valentino's performance of desire. Ready to leave the Grandet household, Charles enters Marguerite's bedroom to say farewell. Their embrace is initially calm, almost timid, and they proceed to exchange keepsakes; Valentino, however, betrays anxiety, as he does not merely hold her or touch her but caresses her again and again, unable to let go, gently squeezing her body with both hands. Then suddenly he grabs her with force, kisses her and holds her tight, steals one more frantic kiss, and is out of the door with desperate speed (fig.17). The earth-shattering intensity of this last embrace is highlighted through its reaction on Marguerite, now left alone on screen, keeping her eyes closed and her hands clasped together, as if still able to feel his body in her hands (fig.18), and reeling from the experience of Charles's passion.

It is this oscillating pattern, this alternation of closeness and isolation, which gives Valentino's performance its marked rhythm. It is also a pattern that follows with startling accuracy Freud's full description of melancholia. Freud remarks how the 'melancholic work of the ego' is not limited to pain, loss of interest in the outside world, and cathexis on an inner tragedy, but it also includes something altogether different: 'The most remarkable characteristic of melancholia [...] is its tendency to change round into mania - a state which is the opposite of it in its symptoms'. ${ }^{19}$ While 
Freud declared himself baffled by this aspect of melancholia, it seems that he had in fact stumbled upon a possible explanation for it, at least in cases when manic behaviour could be linked to a desired object. A few pages earlier, Freud posits the existence of an 'object-choice' to which the melancholic subject has been attached, but which is then perceived as lost because of the 'shattering' (real or imagined) of the relationship that sustained it. Just like in the case of someone experiencing mourning, the melancholic ego refuses to abandon its former attachment, or 'libidinal position', and wishes to 'incorporate' the lost object by means of 'devouring it'. ${ }^{20}$ These last words certainly suggest sex, or more specifically a state of frenzied erotic desire which may be expressed through a range of behaviours. In regards to Valentino's performance, it seems evident that his obsessive hand-kissing, random leg-hugging, and generally frantic engulfment of his partner's body, may signal a desperate if unconscious wish to literally consume the object of his desire. This devouring attempt neatly brings the melancholic cycle to a temporary close.

Freud's work, therefore, suggests that melancholia may be visualised through a specific sequence: contemplation of unbearable loss, accompanied by painful disinterest in the outside world, and by enormous and stubborn focus on a lost object, followed by the effort to defer loss through devouring the object itself. This is the exact pattern that Valentino produces in his performance; and just like the melancholic subject, his characters also have not a clear loss to mourn. Valentino's performative display suggests a sexual melancholia, a relation to erotic feelings defined by the dread and grief of loss, and equally motivated by it. Prey to a shifting disconnection from the outside world, the body is dramatised by Valentino as a place of disorientation and desire, as a vehicle for feelings and sensations that inevitably 
evoke the burden of isolation. In the films examined in this essay, the hidden story of Valentino's characters is one of melancholic erotic experience.

The ambiguity surrounding Valentino's star image, encompassing a gamma of gender-blurring factors, finds then a different expression in this case. In the roles of Armand, Julio, and Charles, Valentino constructs a relation to the sexual and the physical which is essentially subversive. This subversion does not only rest, as it has been argued, on his dualistic masculinity and multiple positioning in the system of the gaze; Valentino is subversive because these already unstable relations are organised through a structuring distress of his male subjectivity. Patriarchal notions of straightforward desire, uncomplicated erotic achievement, and indeed mastery and control, are fatally compromised; instead, Rudolph Valentino presents a troubling spectacle of sexual 'aversion' and chronic dissatisfaction, unsettling traditional notions of virility and eroticism.

\section{NOTES}

${ }^{1}$ In The Sheik (George Melford, 1921) and The Son of the Sheik (George Fitzmaurice, 1926).

${ }^{2}$ As suggested respectively by Miriam Hansen in "Pleasure, Ambivalence, Identification: Valentino and Female Spectatorship", Cinema Journal 25, no.4 (1986): 11; and by Gaylyn Studlar in "'Optic Intoxication': Rudolph Valentino and Dance Madness", in This Mad Masquerade: Stardom and Masculinity in the Jazz Age (New York: Columbia University Press, 1996), 172, 173. 
${ }^{3}$ Andrew Klevan, Film Performance: from Achievement to Appreciation, (London: Wallflower, 2005), 12.

${ }^{4}$ Klevan, Film Performance, 13.

${ }^{5}$ Hansen, "Pleasure, Ambivalence, Identification", 21.

${ }^{6}$ Studlar, “Optic Intoxication”, 189,190.

${ }^{7}$ Thomas J. Slater, "June Mathis's Valentino Scripts: Images of Male 'Becoming' After the Great War", Cinema Journal 50, no.1 (2010), 99-120.

${ }^{8}$ Mark Glancy, " 'For the Purpose of Pleasing Women: British Fan Culture and Rudolph Valentino", in Hollywood and the Americanization of Britain: from the 1920s to the Present (London: I.B. Tauris, 2013), 62, 63.

${ }^{9}$ Glancy, "“For the Purpose of Pleasing Women"”. 63.

${ }^{10}$ Leo Bersani, "Is the Rectum a Grave?", in Is the Rectum a Grave? and Other Essays (Chicago: University of Chicago Press, 2010), 3.

${ }^{11}$ Bersani, “Is the Rectum a Grave?”, 22, 23.

${ }^{12}$ Bersani, "Is the Rectum a Grave?", 24.

${ }^{13}$ Bersani, "Is the Rectum a Grave?", 23.

${ }^{14}$ Leo Bersani, “Can Sex Make Us Happy?”, in Is the Rectum a Grave? and Other Essays (Chicago: University of Chicago Press, 2010), 120-132.

${ }^{15}$ Bersani, “Can Sex Make Us Happy?”, 126; quoting from Sigmund Freud, Civilization and Its Discontents (Harmondsworth: Penguin Books, 2002), 41.

${ }^{16}$ It did not absolutely exclude it, though. As it was customary for Freud, a seemingly random sentence in 'Mourning and Melancholia' provides a glimpse of other potential, yet unexplored avenues of research: '... some of these [melancholic] forms suggest somatic rather than psychogenic affections.' ("Mourning and Melancholia", in On Metapsychology (Harmondsworth: Penguin Books, 1984), 251.

${ }^{17}$ Freud, "Mourning and Melancholia", 252.

${ }^{18}$ Freud, "Mourning and Melancholia", 253.

${ }^{19}$ Freud, "Mourning and Melancholia", 262.

${ }^{20}$ Freud, "Mourning and Melancholia", 258. 


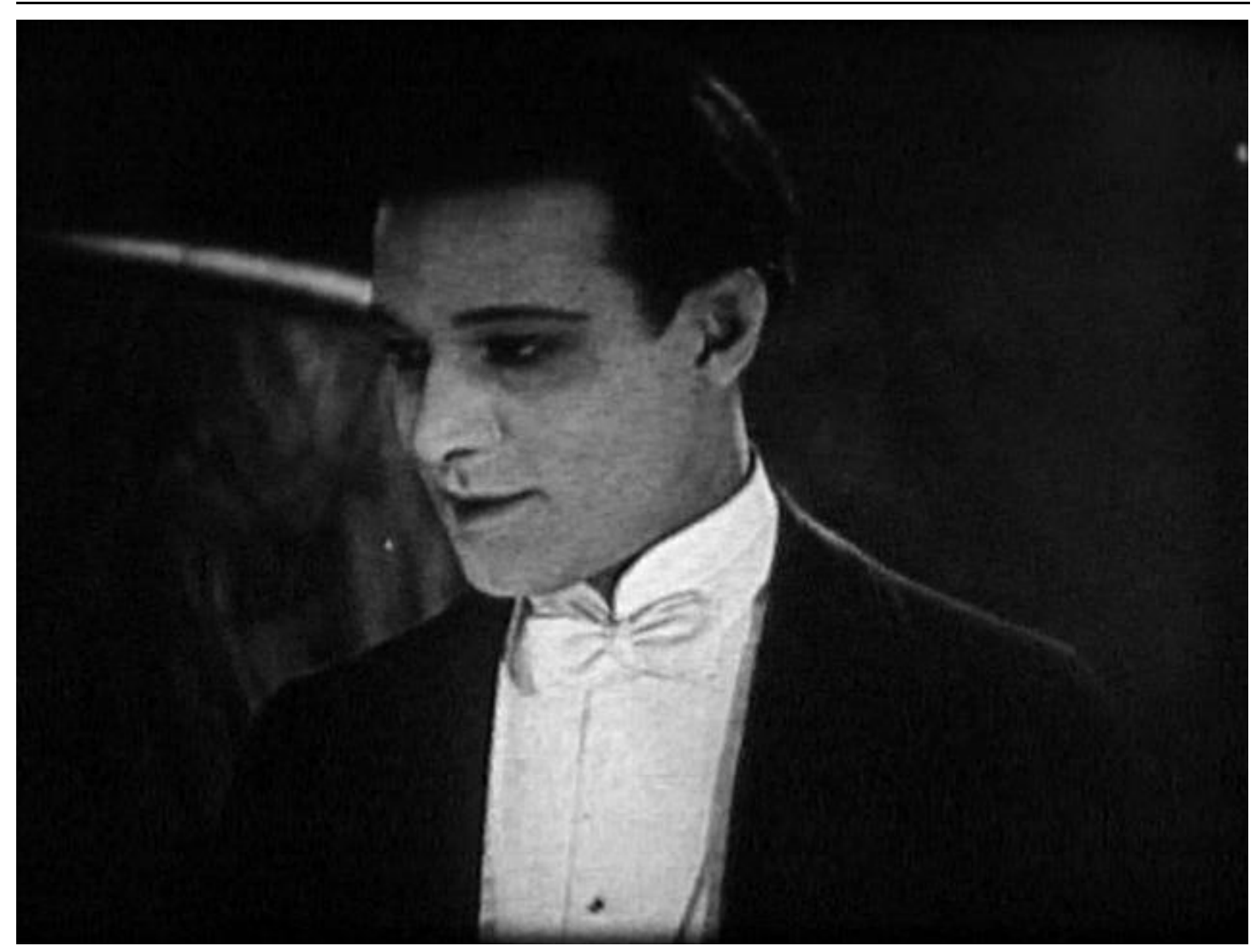

Fig. 1

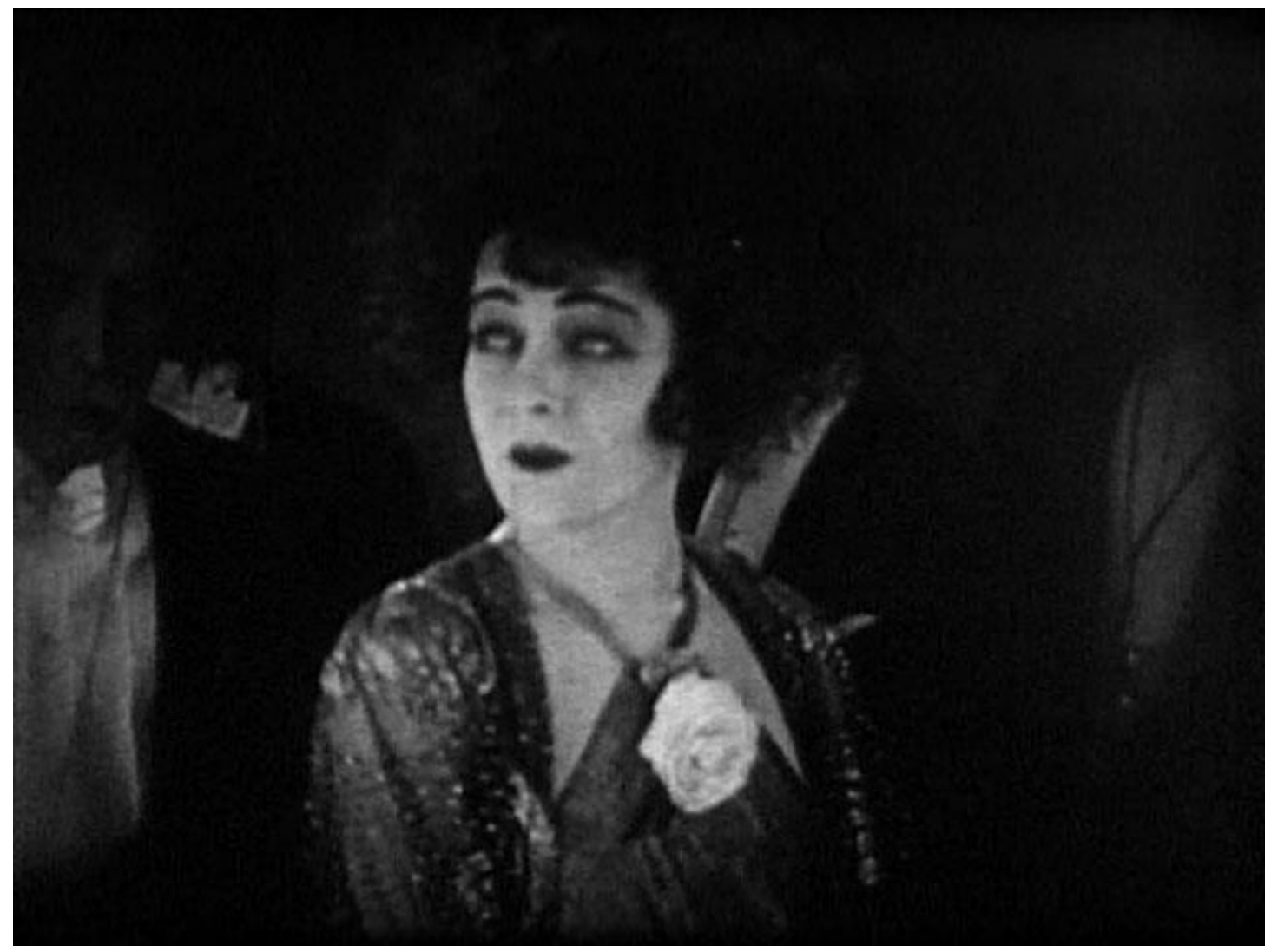

Fig. 2 


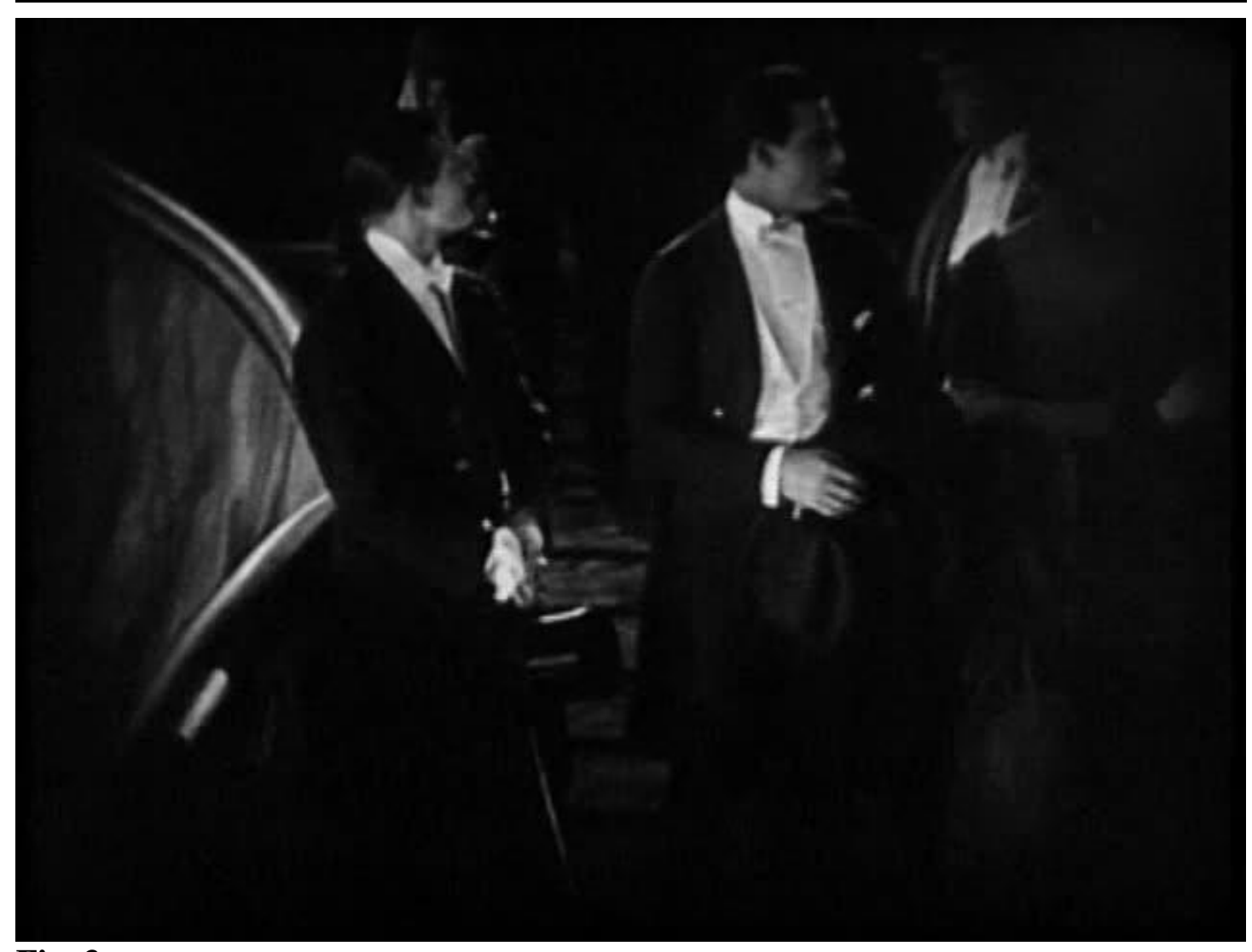

Fig. 3

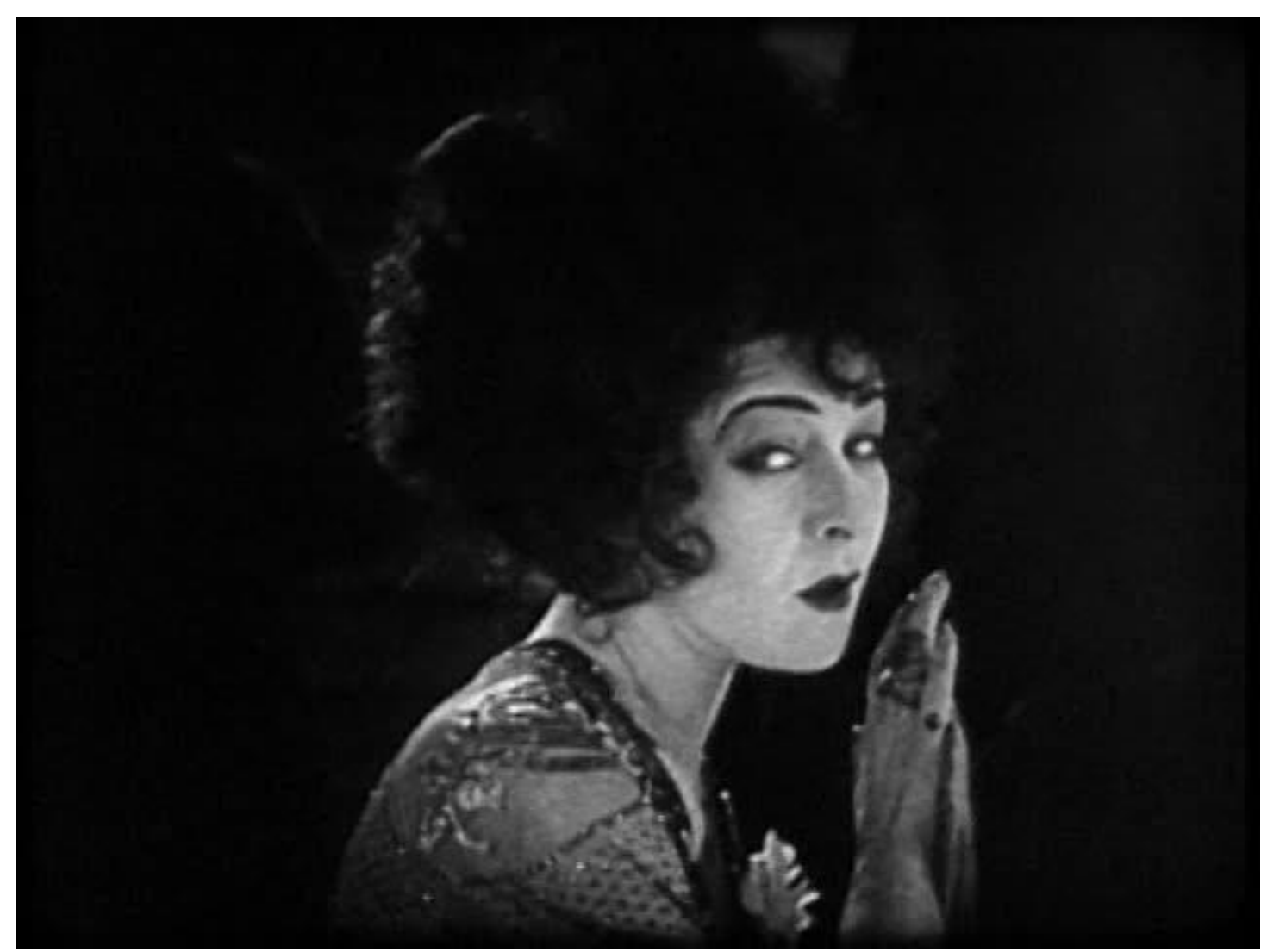

Fig. 4 


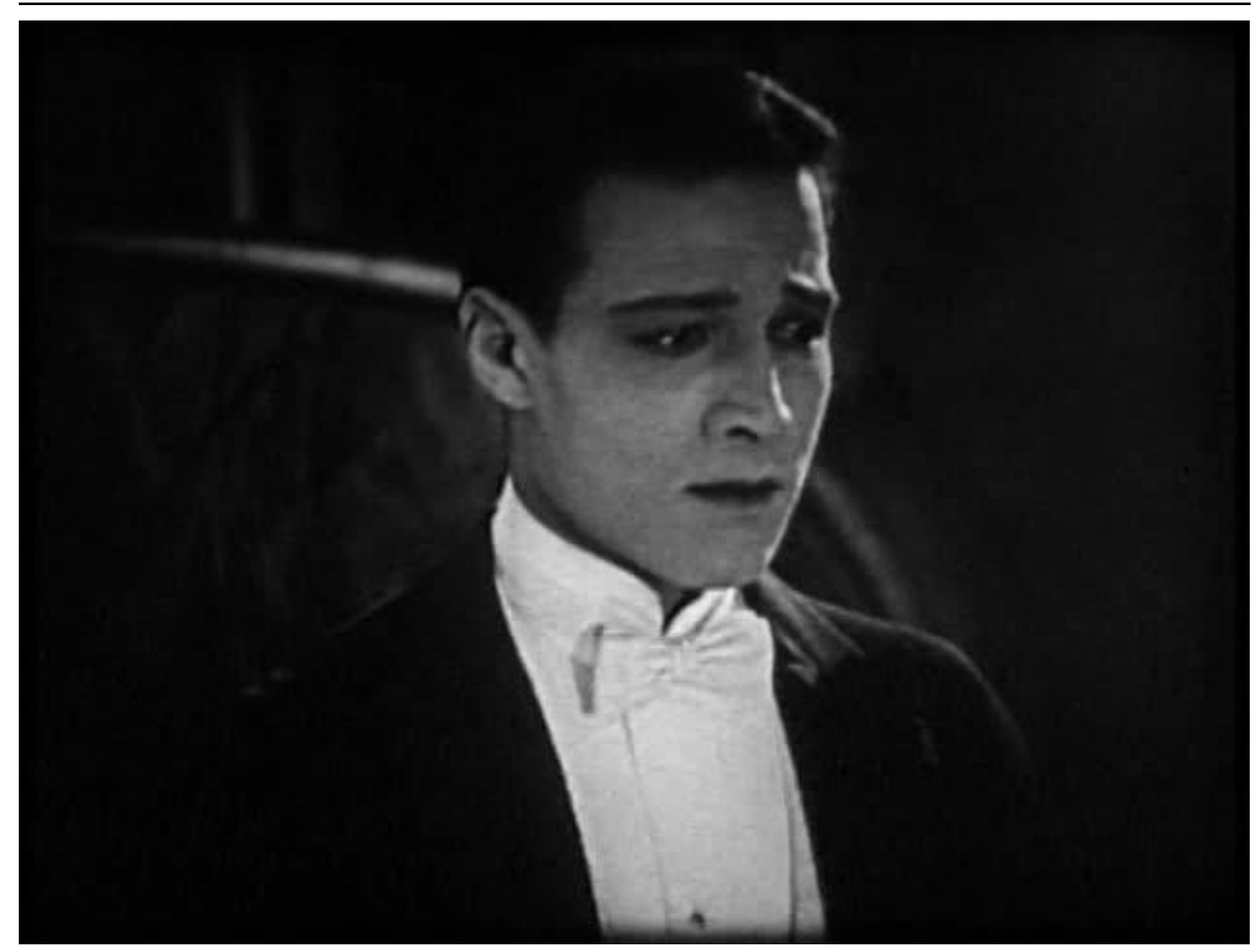

Fig. 5

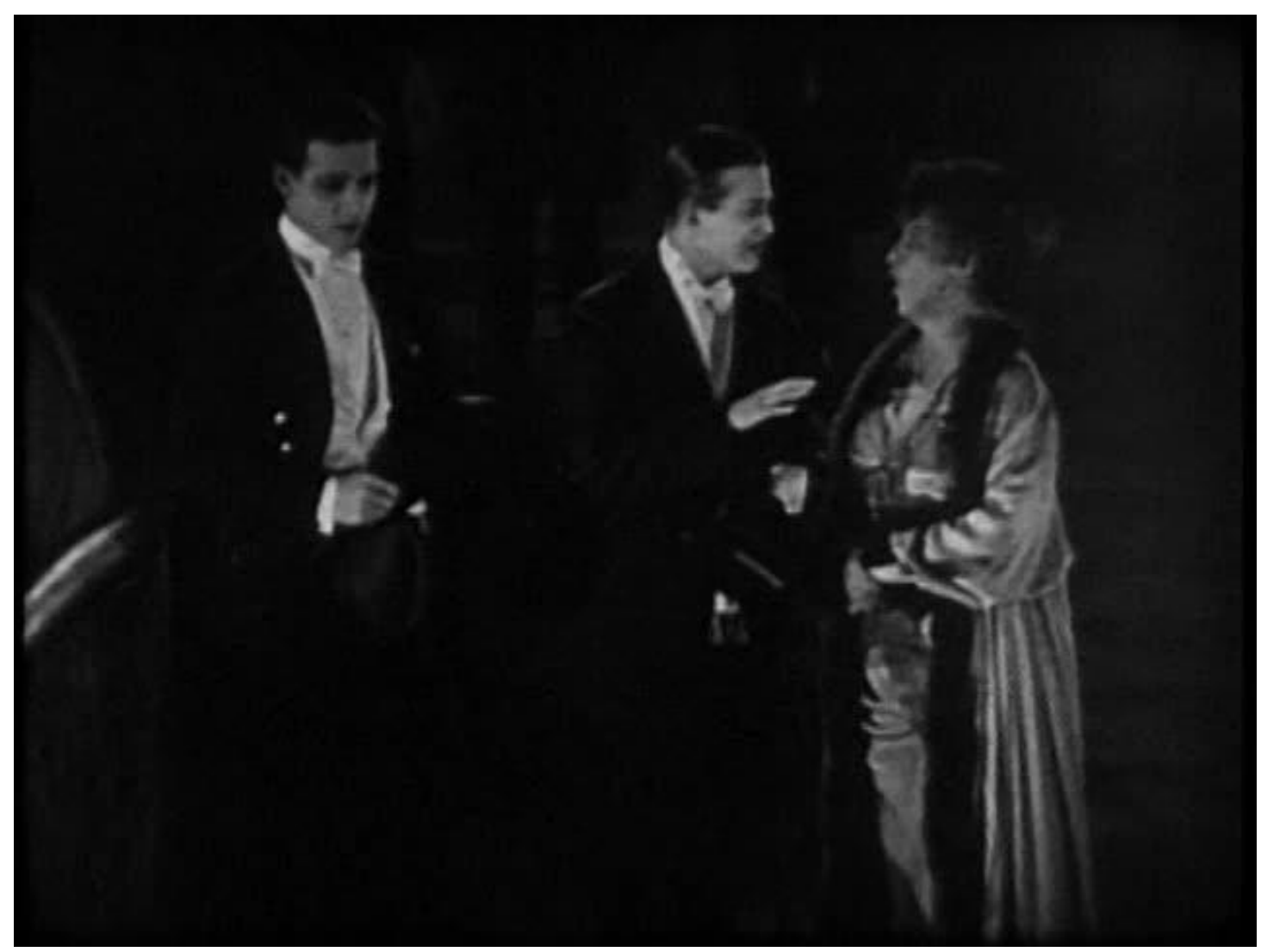

Fig. 6 


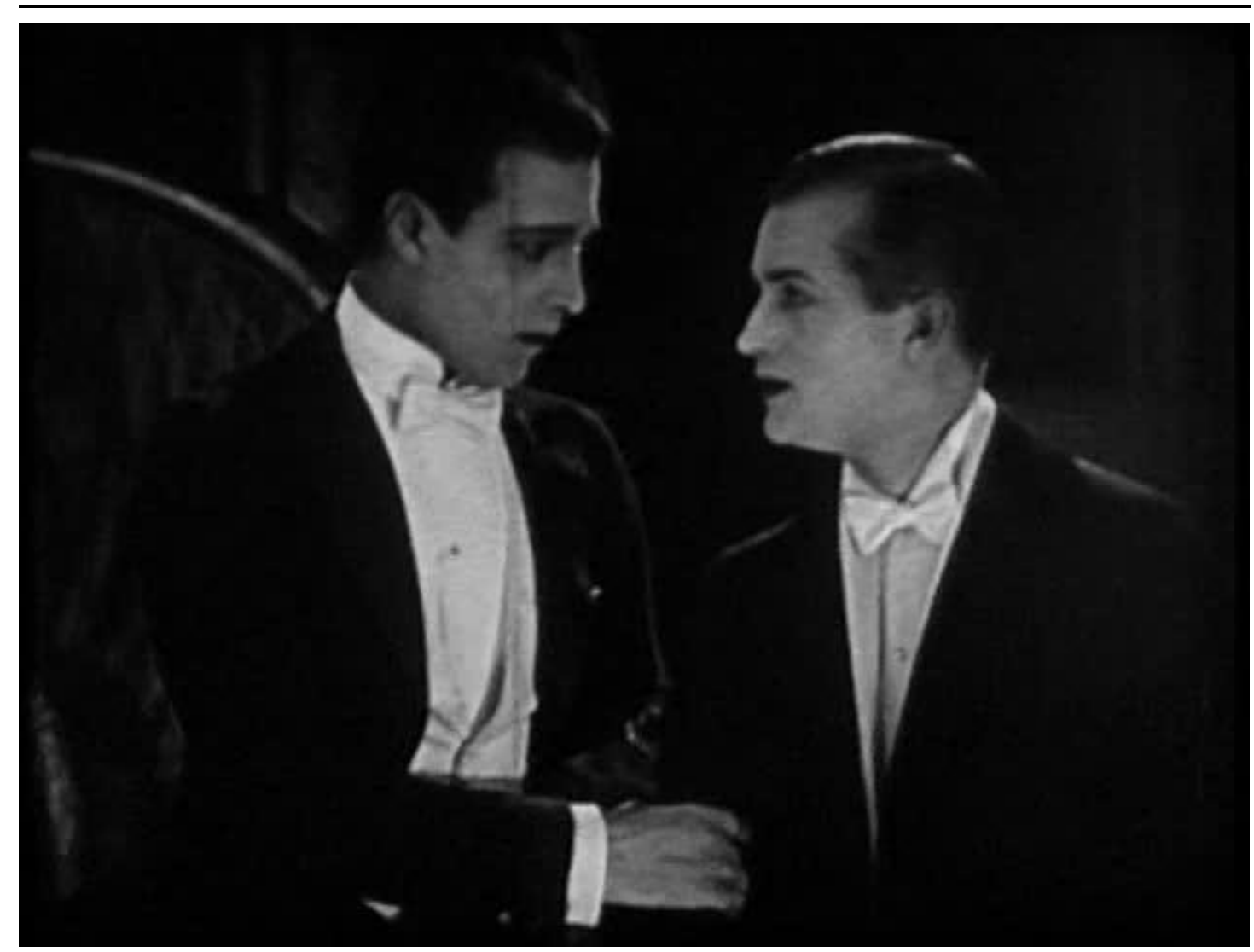

Fig. 7

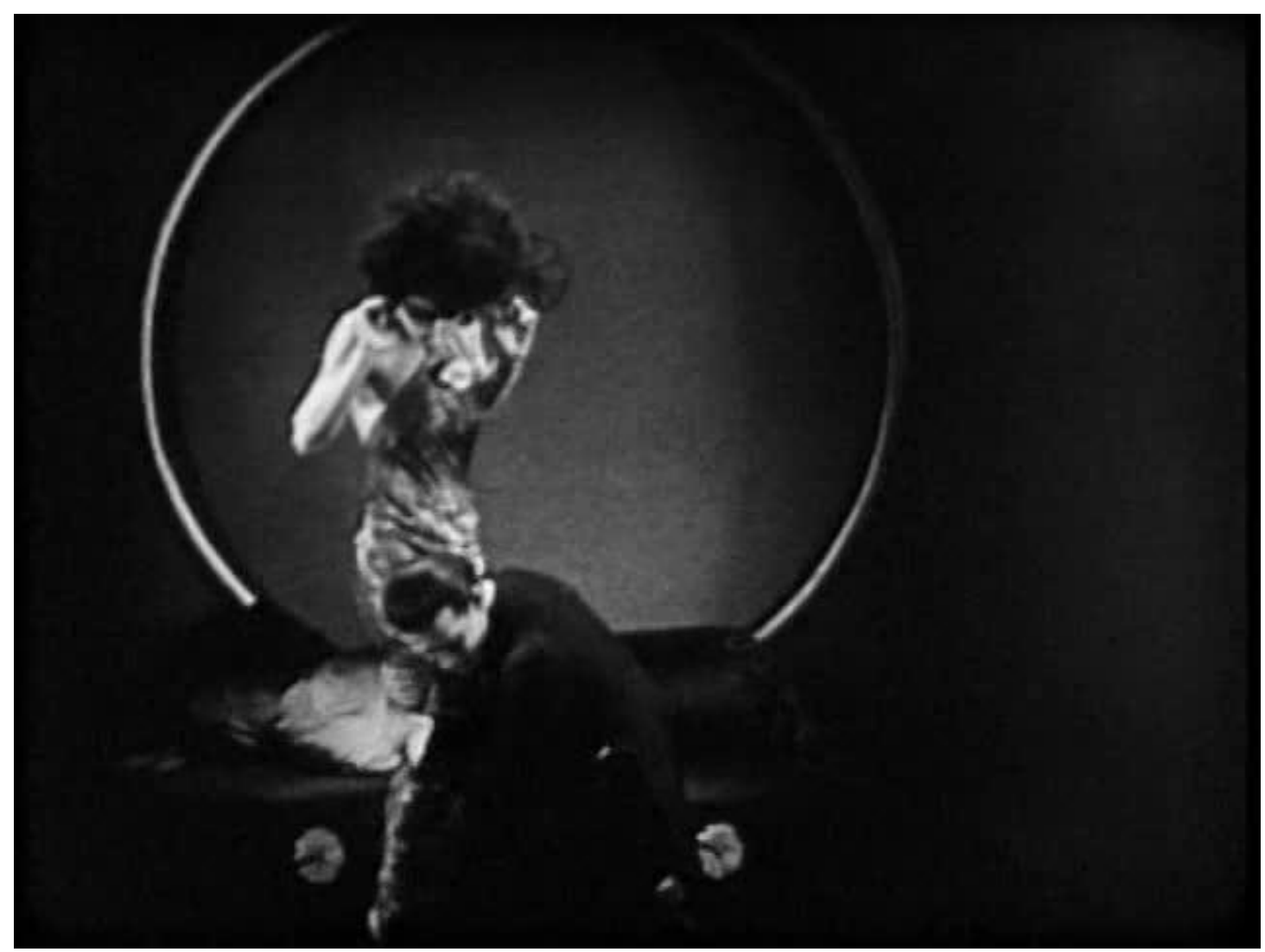

Fig. 8 


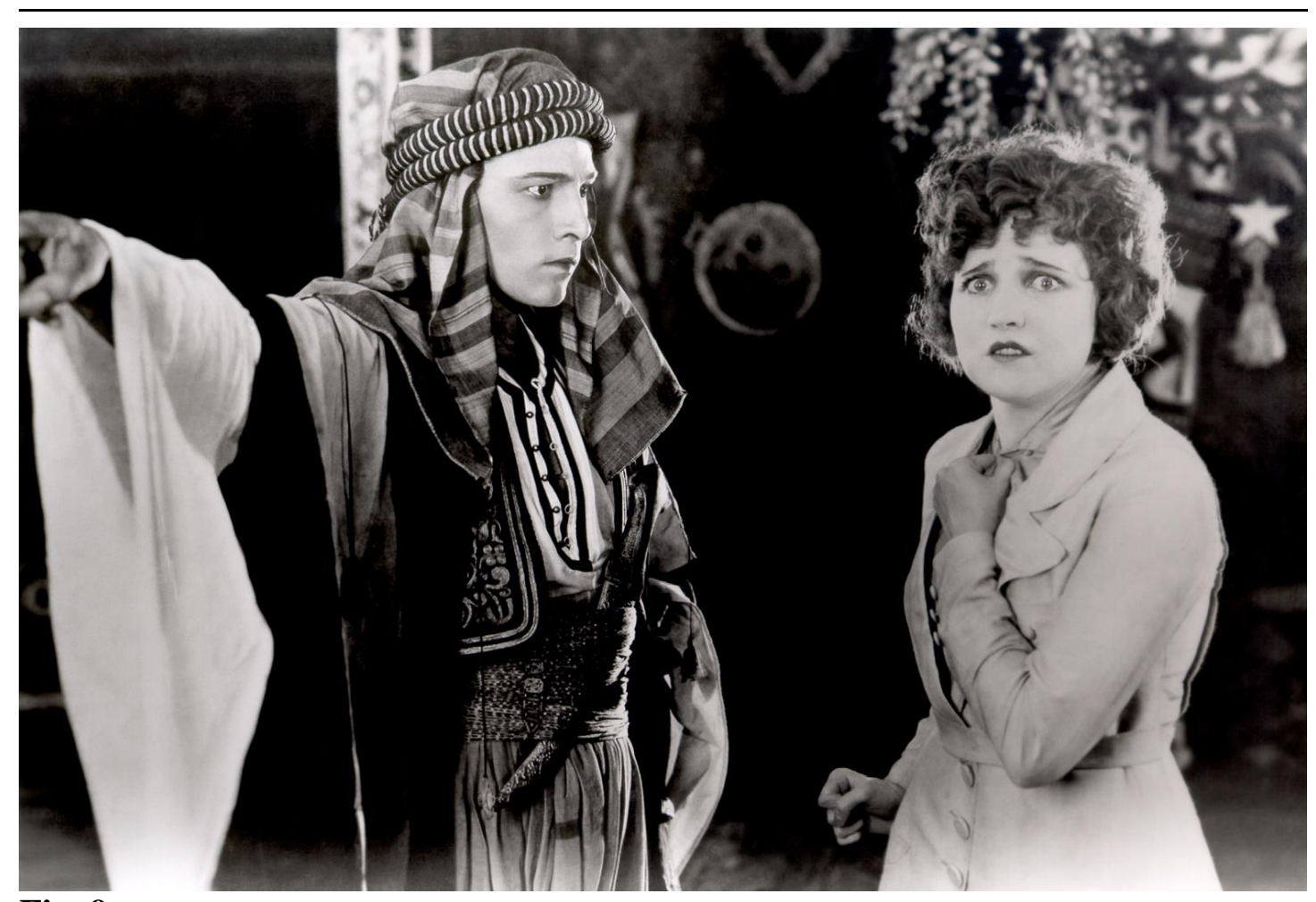

Fig. 9

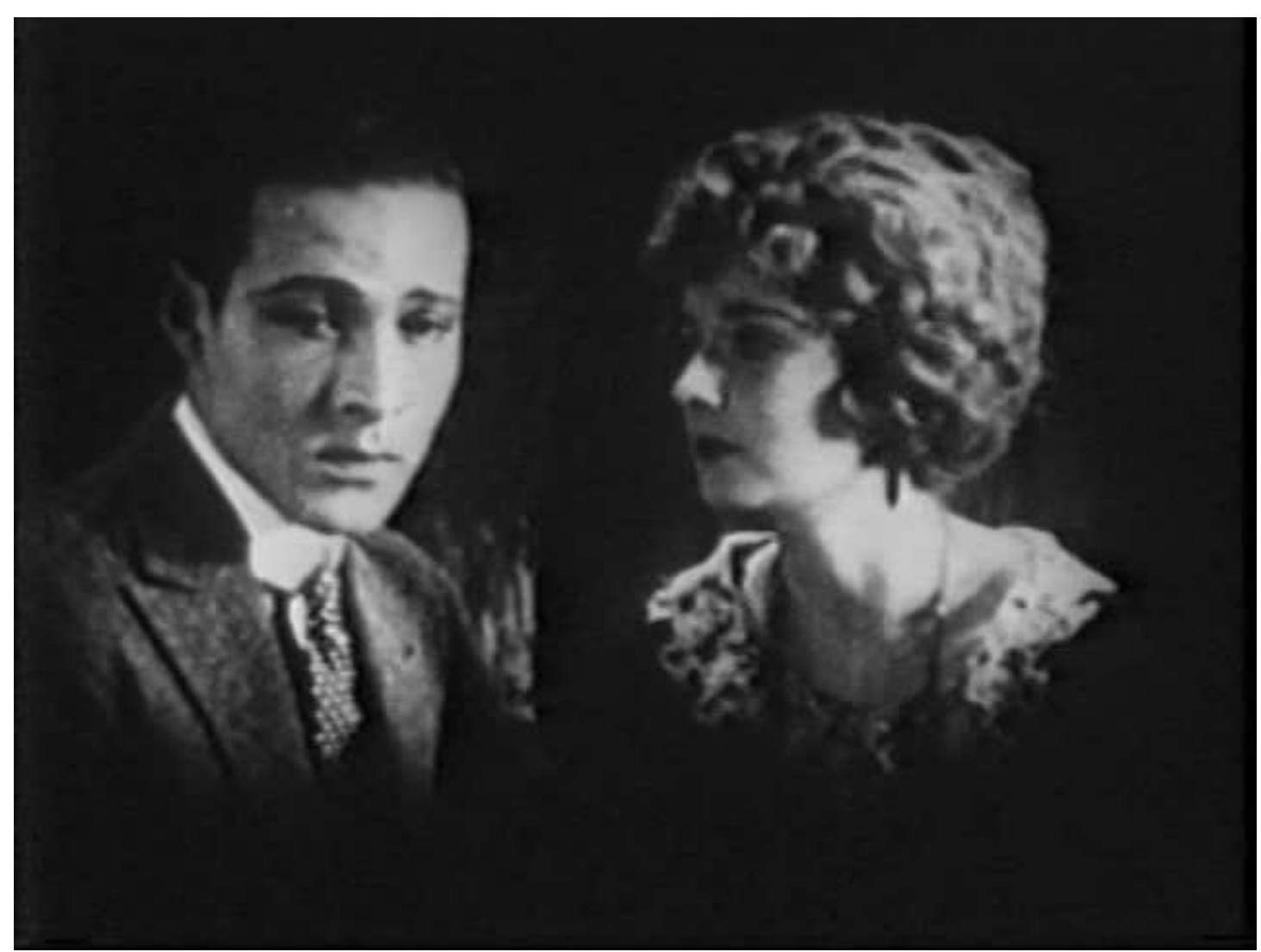

Fig. 10 


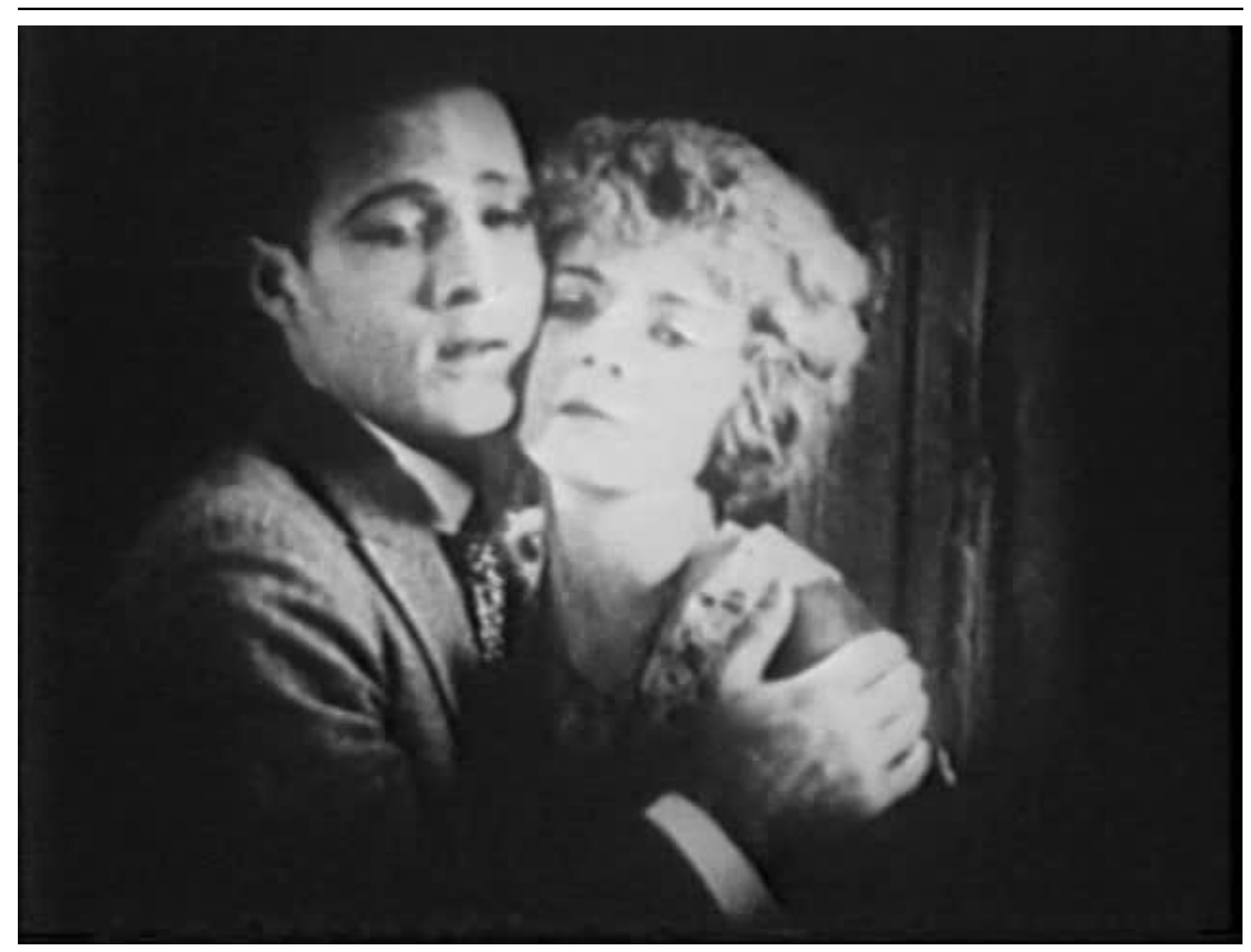

Fig. 11

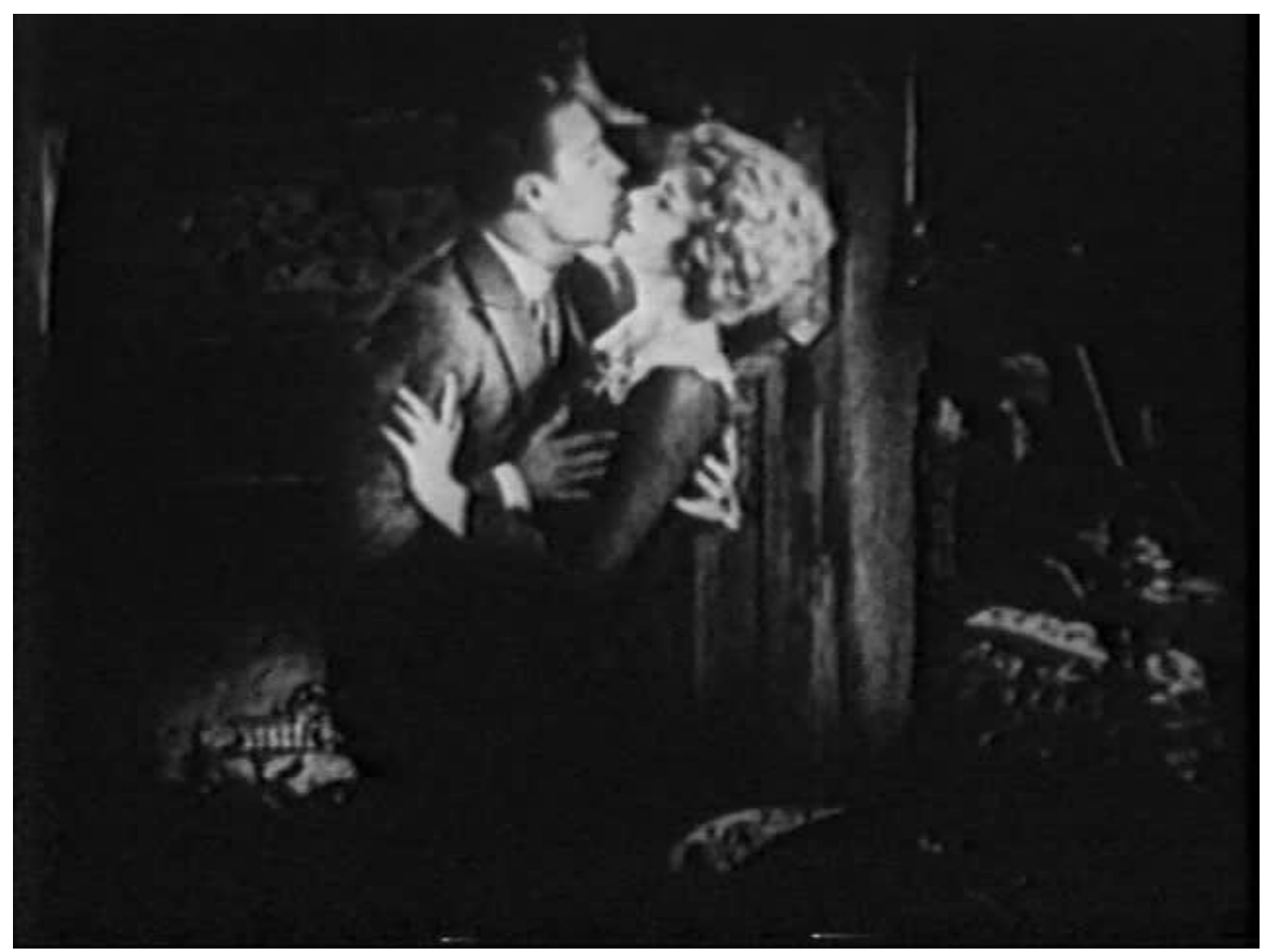

Fig. 12 


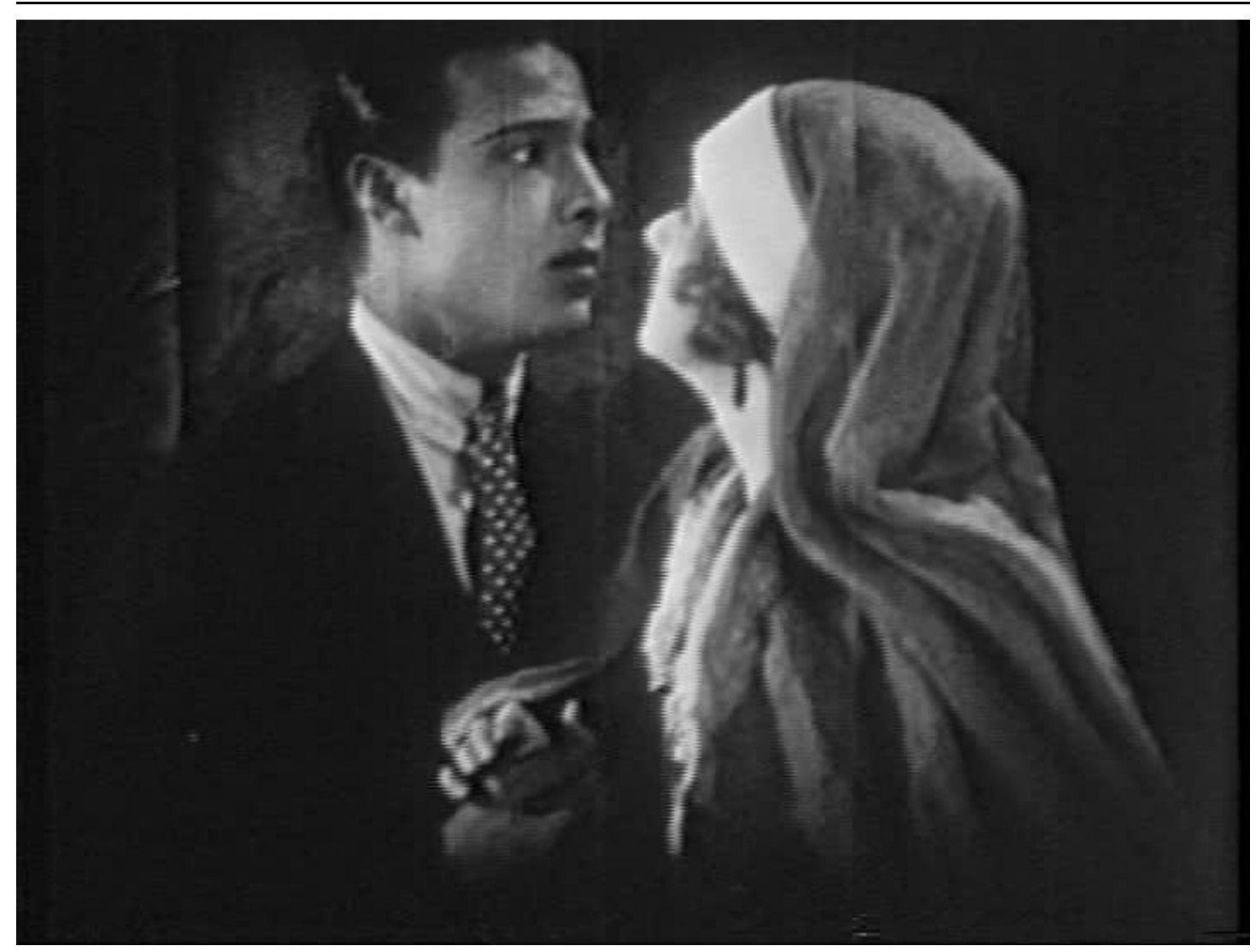

Fig. 13

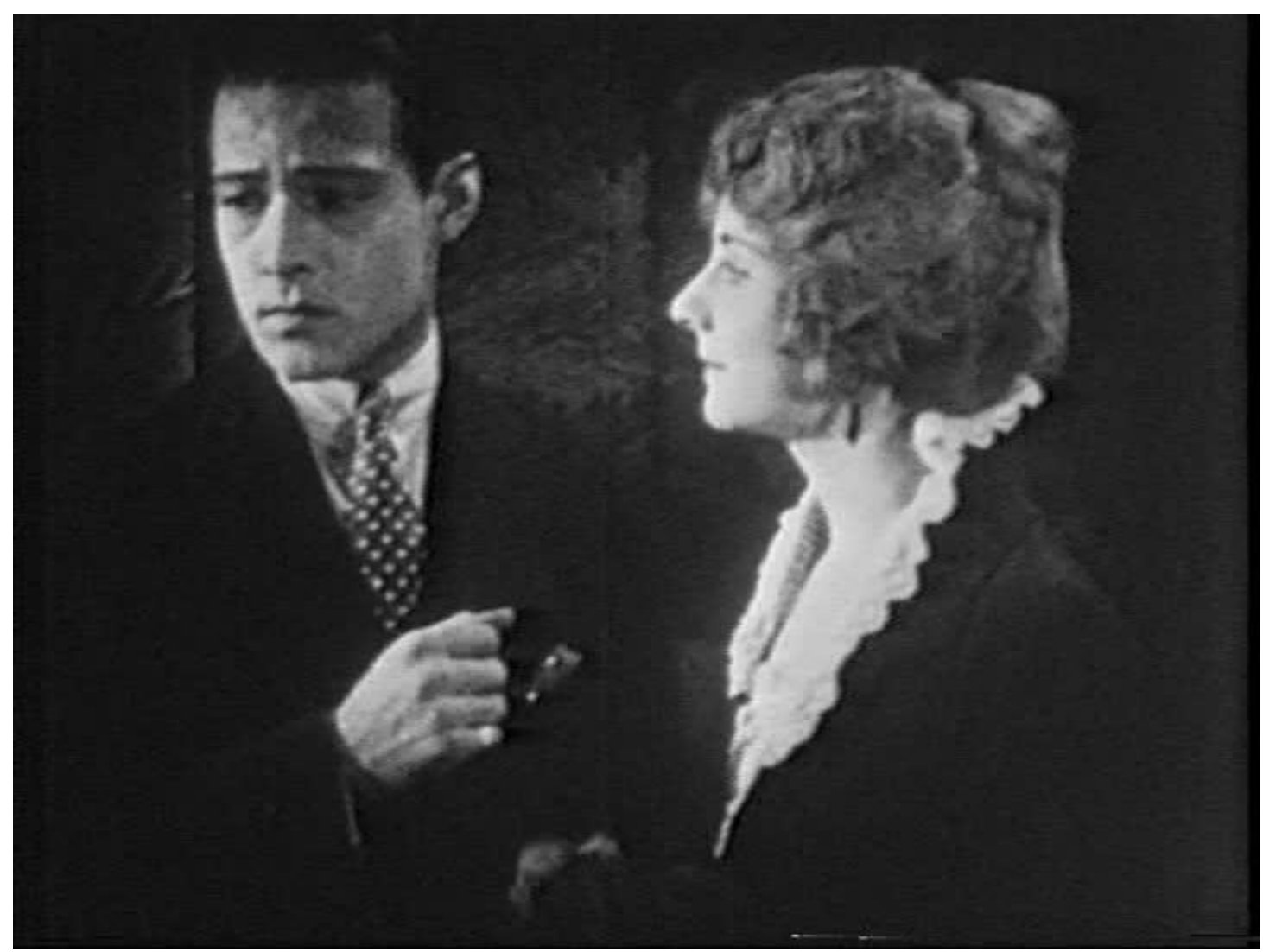

Fig. 14 


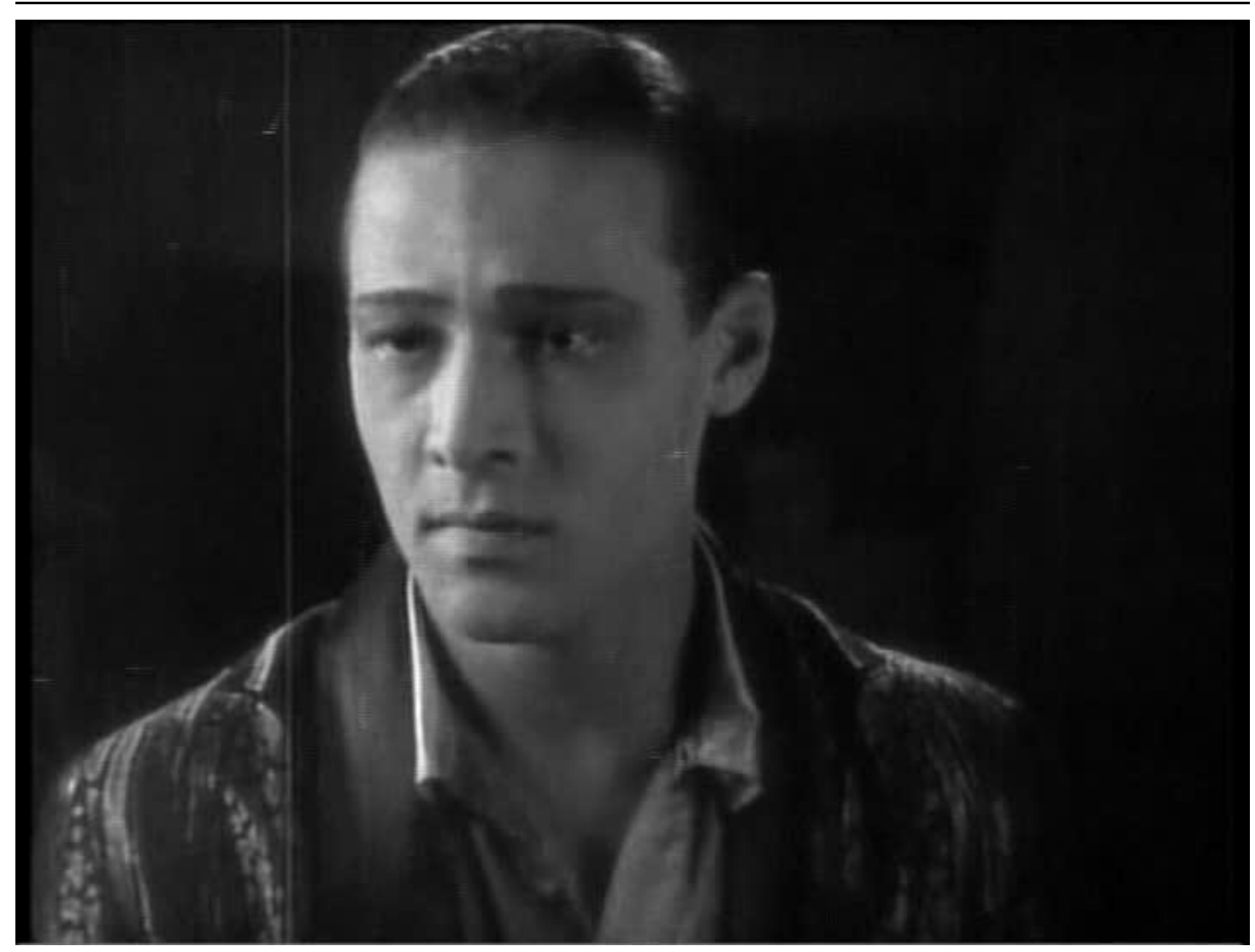

Fig. 15

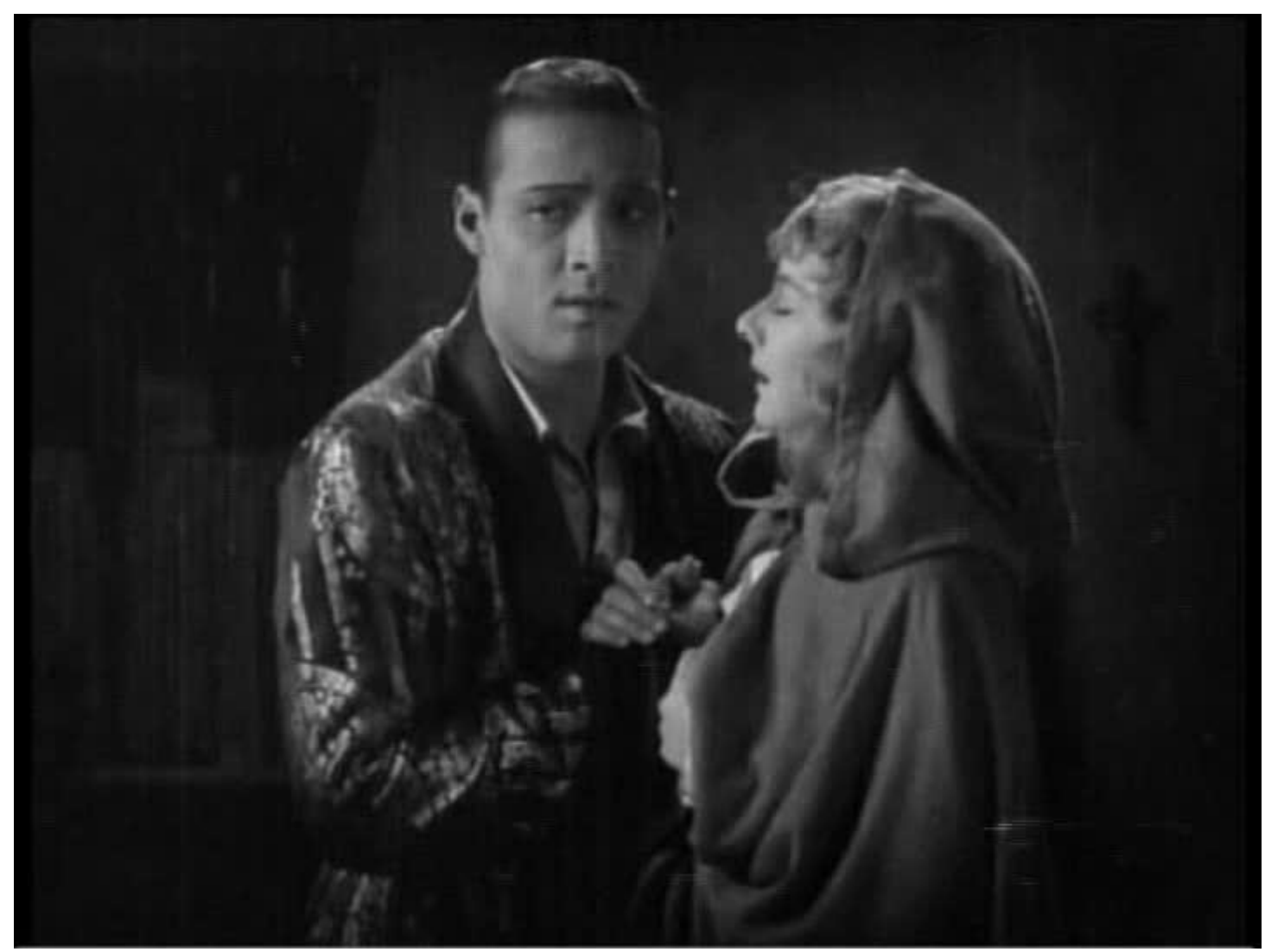

Fig. 16 


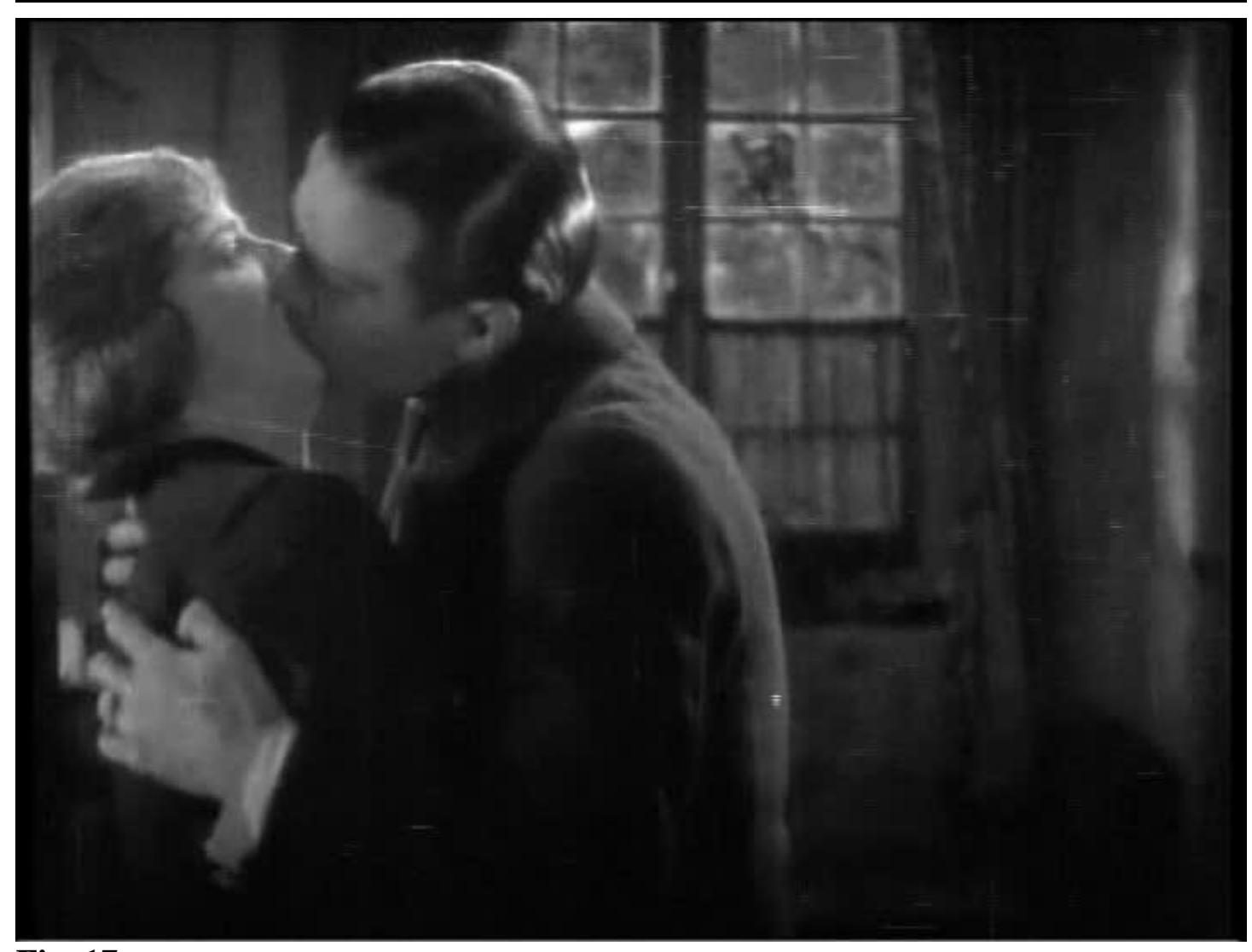

Fig. 17

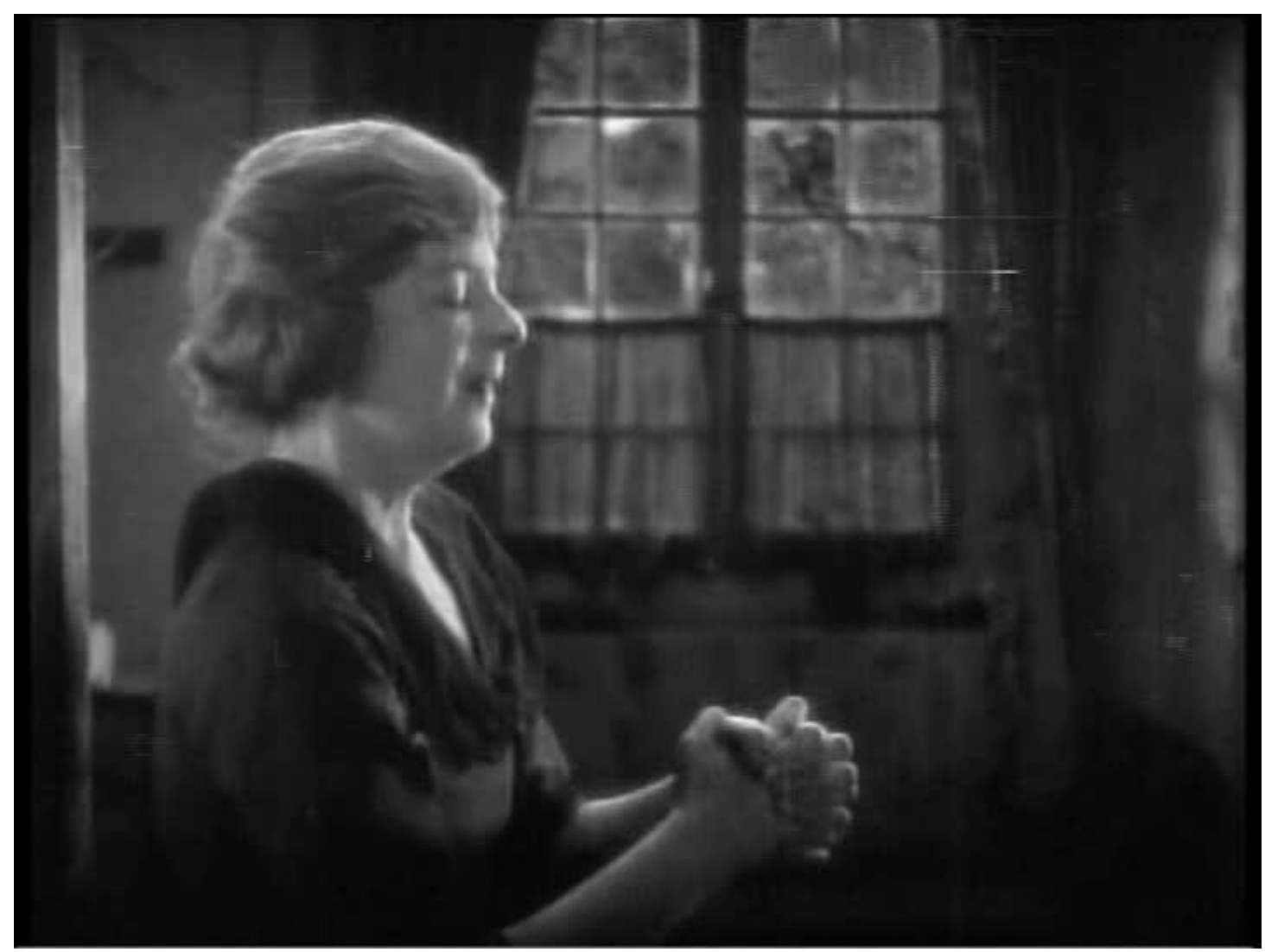

Fig. 18 